\title{
Australia
}

Financial sector reform legislation by Paul Latimer

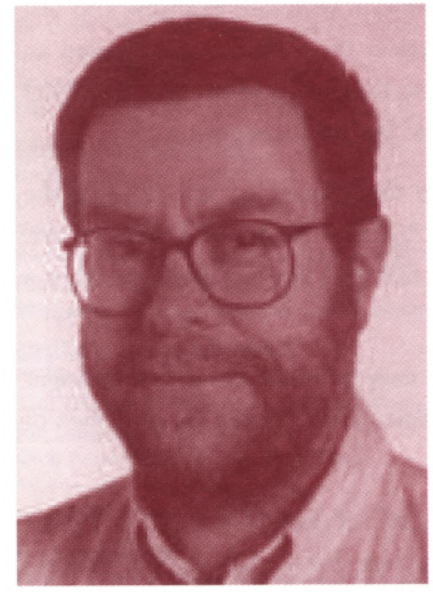

$\mathrm{A}$ ustralian consumer protection laws in the financial sector have been moved as from 1 July 1998 from the Trade Practices Act 1974 (Cth) (hereafter 'the TPA') to the Australian Securities and Investments Commission Act 1989 (Cth) (hereafter 'the ASIC Act') into a new division called 'Unconscionable conduct and consumer protection in relation to consumer services' (s. 12AA-121A).

Before the amendments, consumer protection in the financial sector was in the hands of Australia's competition and consumer protection watchdog, the Australian Competition and Consumer Commission (ACCC). The ACCC is a high profile regulator with an impressive track record over almost 25 years.

These amendments give effect to Recommendation 3 of the Wallis Committee Report, namely that Australia's corporate and securities regulator should administer all consumer protection laws for financial services to avoid regulatory duplication in the financial system, on the basis that it creates additional compliance costs, uncertainty and the risk of inconsistency.

\section{on the internet}

http:www.treasury.gov.au/fsi

See the Financial System Inquiry Final Report, Australian Government Publishing Service, 1997, on this website

The TPA sections are now paralleled in the ASIC Act. The amendments to the ASIC Act apply to a 'financial service', defined to mean a service that:

'(a) consists of providing a financial product; or

(b) is otherwise supplied in relation to a financial product.'

A 'financial product' is defined to mean:

(a)'a facility for taking money on deposit ... made available in the course of conducting a banking business ... or

(b) a security; or ...

(c) a future contract; or

(d) a contract of insurance ... or

(e) a retirement savings account ... or

(f) a superannuation interest.

but does not include a foreign exchange contract.'

The key section is s. 12DA, the ASIC Act version of TPA s. 52:

'A corporation must not, in trade or commerce, engage in conduct in relation to financial services that is misleading or deceptive or is likely to mislead or deceive.'
Section 52 has proven to be the single most important section in Australian commercial law. It can be litigated by the regulator, as well as by private action and, in the latter category, s. 52 has been used as the basis for litigation in misrepresentation; as an alternative remedy for breach of contract and tort (negligence, defamation and passing off); in cases involving competitor $\mathrm{v}$ competitor, breach of copyright and disputes involving bankruptcy, partnerships, companies, receivers, share issues, prospectuses and take-overs.

Other ASIC Act clones of the TPA in force on 1 July 1998 prohibit:

- false or misleading representations (TPA s. 53; now ASIC Act s. $12 \mathrm{DB})$;

- false representations and other misleading or offensive conduct in relation to securities that involve interests in land (TPA s. 53A; ASIC Act s. 12 DC);

- not stating the cash price (TPA s. 53C; ASIC Act s. 12DD);

- offering gifts and prizes (TPA s. 54; ASIC Act s.12DE);

- certain misleading conduct in relation to financial services (TPA s. 55; ASIC Act s. 12DF);

- bait advertising (TPA s. 56; ASIC Act s. 12DG);

- referral selling (TPA s. 57; ASIC Act s. 12DH);

- accepting payment without intending or being able to supply as ordered (TPA s. 58A; ASCI Act s. 12DI);

- harassment and coercion (TPA s. 60; ASIC Act s. 12DJ)

- pyramid selling of securities (TPA s. 61; ASIC Act s. 12 DK);

- unsolicited credit and debit cards that allow access to a financial product (TPA s. 63A; ASIC Act s. 12DL);

- assertion of right to payment for unsolicited financial services (TPA s. 64; ASIC s. 12DM).

Section $12 \mathrm{DN}$ applies the Division to the print and electronic media under the name of 'prescribed information providers' (TPA s. 65A; ASIC s. 12DN).

Those having dealings with the Australian financial sector must be aware especially of s. 12DA, and of this important changing of the guard of Australian market regulators from the ACCC to the ASIC.

\section{FURTHER READING}

The ACCC homepage can be found on http://www.accc.govau and that of the ASIC on http://www.asic.govau. For the Department of Business Law and Taxation, Monash University, the website is: http//www.buseco.monash.edu.au/Depts/BLT/.

Paul Latimer

Head, Department of Business Law and Taxation, Monash University, Melbourne, Australia 